\title{
Beyond Concurrent Chemoradiation: The Emerging Role of PD-1/ PD-L1 Inhibitors in Stage III Lung Cancer.
}

\author{
Neal S. McCall \\ Thomas Jefferson University \\ Adam P. Dicker \\ Thomas Jefferson University \\ Bo Lu \\ Thomas Jefferson University
}

Follow this and additional works at: https://jdc.jefferson.edu/radoncfp

Part of the Oncology Commons, and the Radiology Commons

Let us know how access to this document benefits you

\section{Recommended Citation}

McCall, Neal S.; Dicker, Adam P.; and Lu, Bo, "Beyond Concurrent Chemoradiation: The Emerging Role of PD-1/PD-L1 Inhibitors in Stage III Lung Cancer." (2018). Department of Radiation

Oncology Faculty Papers. Paper 104.

https://jdc.jefferson.edu/radoncfp/104

This Article is brought to you for free and open access by the Jefferson Digital Commons. The Jefferson Digital Commons is a service of Thomas Jefferson University's Center for Teaching and Learning (CTL). The Commons is a showcase for Jefferson books and journals, peer-reviewed scholarly publications, unique historical collections from the University archives, and teaching tools. The Jefferson Digital Commons allows researchers and interested readers anywhere in the world to learn about and keep up to date with Jefferson scholarship. This article has been accepted for inclusion in Department of Radiation Oncology Faculty Papers by an authorized administrator of the Jefferson Digital Commons. For more information, please contact: JeffersonDigitalCommons@jefferson.edu. 
Beyond Concurrent Chemoradiation: The Emerging Role of PD-1/PD-L1 Inhibitors in Stage III Lung Cancer

Neal S. McCall ${ }^{1}$, Adam P. Dicker ${ }^{1}$, Bo Lu ${ }^{1}$

${ }^{1}$ Department of Radiation Oncology, Thomas Jefferson University Hospitals, Philadelphia, PA

Running Title: PD-1/PD-L1 Inhibitors in Stage III Lung Cancer

Keywords: Lung Cancer, Clinical Research, Immunotherapy

Conflicts of Interest: Dr. Lu reports his role on an advisory board for AstraZeneca. The authors have no other conflicts of interest to disclose.

Word Count: 2357

Tables: 3

Figures: 1

*Corresponding Author:

Bo Lu, MD, PhD

Department of Radiation Oncology Thomas Jefferson University and Hospitals

111 South 11th Street Philadelphia, PA 19107

Phone: 215-955-6705

Fax: 215-503-0013

E-mail: bo.1u@jefferson.edu 


\section{Translational Relevance}

Preliminary results of the recent PACIFIC trial established clinical evidence of therapeutic synergy between PD-1 or PD-L1 immune checkpoint blockade and chemoradiation. PD-L1 inhibitor durvalumab is the first consolidative therapy to reduce risk of disease progression or death after concurrent chemoradiation (cCRT) in patients with unresectable Stage III non-small cell lung cancer (NSCLC), although outcomes remain blinded to overall survival. Further efforts to incorporate immune checkpoint inhibitors should focus on accurate biomarker development and patient selection and the ideal sequence or combinations of immunotherapy and chemoradiation. 


\begin{abstract}
Concurrent chemoradiation (cCRT) with platinum-based chemotherapy is standard of care therapy for patients with Stage III unresectable non-small cell lung cancer (NSCLC). Though potentially curative, five-year overall survival has hovered around $20 \%$, despite extensive efforts to improve outcomes with increasing doses of conformal radiation and intensification of systemic therapy with either induction or consolidation chemotherapy. PD-1/PD-L1 immune checkpoint inhibitors have demonstrated unprecedented efficacy in patients with Stage IV NSCLC. Additionally, preclinical and early clinical evidence suggests that chemotherapy and radiation may work synergistically with anti-PD-1/PD-L1 therapy to promote anti-tumor immunity, which has led to the initiation of clinical trials testing these drugs in patients with Stage III NSCLC. A preliminary report of a randomized phase III trial, the PACIFIC trial, demonstrated an impressive increase in median progression-free survival with consolidative durvalumab, a PD-L1 inhibitor, compared to observation after cCRT. Here, we discuss the clinical and translational implications of integrating PD-1/PD-L1 inhibitors in the management of patients with unresectable Stage III NSCLC.
\end{abstract}




\section{Concurrent Chemoradiation in Stage III NSCLC}

Concurrent chemoradiation (cCRT) became standard of care in the treatment of unresectable Stage III non-small cell lung cancer (NSCLC) following the RTOG-9410 study, which reported improved overall survival (OS) with cCRT compared to sequential chemoradiation (1). However, five-year OS rates have hovered around 15-20\%, and distant failures, often in the brain, are common (2-4). Radiation dose escalation, induction chemotherapy, and consolidative chemotherapy have failed to improve and, at times, worsened outcomes. For example, dose escalation to $74 \mathrm{~Gy}$ from $60 \mathrm{~Gy}$ in the RTOG-0617 trial actually decreased median OS (20.3 vs. 28.7 months; $p=0.004)$ (3). Induction carboplatin and paclitaxel in the CALGB-39801 study increased toxicity without survival benefit (5). Consolidative docetaxel (6), docetaxel and cisplatin (2), and cetuximab (3) following cCRT all failed to increase progression-free survival (PFS) or OS (Table 1). Gefitinib in a study population without selection for EGFR mutations after cCRT and docetaxel also worsened survival (7). The START trial assessed tecemotide following either sequential or cCRT. Although tecemotide appeared to increase PFS and OS in patients treated with prior cCRT (Table 1), it did not significantly change OS in the patients who had been treated with sequential chemoradiation or in a combined analysis of sequential and cCRT ( $\mathrm{p}=0.0123$ ), which has limited its generalization (8).

\section{PD-1/PD-L1 Inhibitors in Stage IV NSCLC}

PD-1/PD-L1 immune checkpoint inhibitors (ICIs) have proven effective in patients with metastatic or recurrent NSCLC (Table 2). Trials of second-line pembrolizumab, nivolumab, and atezolizumab conveyed increased OS compared to chemotherapy in patients previously treated with platinum-based chemotherapy for metastastic NSCLC or tyrosine-kinase inhibitors in the 
setting of EGFR mutations or ALK translocation (Table 2) (9-12). Pembrolizumab remains the only PD-1 inhibitor to improve OS in the first-line setting $(13,14)$. The KEYNOTE-024 trial included patients with recurrent or metastatic NSCLC and PD-L1 expression $\geq 50 \%$ who had not previously progressed on platinum-doublet chemotherapy. First-line pembrolizumab in this study extended PFS and OS in patients with less toxicity than chemotherapy (Table 2) (13). An updated analysis reported a median OS of 30 months with first-line pembrolizumab (15), surpassing figures historically reported from trials of cCRT in Stage III NSCLC $(1,2,6-8)$. These unprecedented results open the possibility of their incorporation into definitive regimens.

\section{Rationale for PD-1/PD-L1 inhibition with Chemoradiation}

Though effective alone, the benefits of PD-1/PD-L1 blockade may be enhanced by chemoradiation (16-18). Mechanistically, radiation triggers antigen release by inducing tumor apoptosis or necroptosis and generates double-stranded DNA breaks, which then activate the interferon-inducing cGAS/STING pathway (19). Cellular catastrophe increases release of the antigen-presenting cell (APC) activators ATP and HMGB1 and translocation of calreticulin, promoting phagocytosis (20). Platinum-based chemotherapy can lead to immunogenic cell death alone, but it also sensitizes cancer to radiation-induced DNA damage and potentiates HMGB1 and ATP release (20). After tumor cell phagocytosis, APCs migrate to lymph nodes and prime Tcells with tumor-specific antigen (19). $\mathrm{CD} 8^{+} \mathrm{T}$ cells can then promote tumor-specific killing. However, PD-L1 is upregulated following irradiation $(21,22)$ and chemotherapy $(23)$, prompting T-cell apoptosis and anergy upon ligation to PD-1 and restricting the immune response (Figure 1) $(24,25)$. The addition of anti-PD-1/ PD-L1 blocks this interaction, facilitating synergistic antitumor immunity (Figure 1) $(21,22)$. 
Early clinical evidence supports this hypothesis of immunogenic synergy between immunotherapy and chemotherapy or radiation. A post-hoc analysis of a phase I trial of pembrolizumab in patients with metastatic NSCLC found increased OS in patients treated with prior radiation (26). In the phase II KEYNOTE-021 trial of patients with non-squamous metastatic or recurrent NSCLC who had not been selected based on PD-L1 expression, concurrent carboplatin, pemetrexed, and pembrolizumab yielded remarkably high response rates of 55\% (27) even without selecting PD-L1 positive patients. This evidence, coupled with what has been a dismal prognosis, provides further rationale for PD-1/PD-L1 ICIs in Stage III NSCLC.

\section{Consolidative Durvalumab in Stage III NSCLC}

Preliminary results of the PACIFIC trial, a Phase III, placebo-controlled trial comparing the PD-L1 ICI durvalumab against observation after cCRT, were recently reported (28). Durvalumab increased PFS by 11 months compared to observation after cCRT, striking compared to results from prior trials of consolidative therapy (Table 1). Responses proved durable: no patients deemed partial or complete responders at 12 months progressed 6 months after discontinuing durvalumab. After a median follow-up of 14.5 months, durvalumab decreased distant failures (20\% vs. $32 \%)$, including brain metastases (5.5\% vs. $11 \%$ ) (28). Thus, the systemic disease control which was previously unattainable with consolidative chemotherapy may be possible with durvalumab. Durvalumab was also remarkably tolerable, as it only slightly increased grade 3 or 4 toxicities (29.9\% vs. $26.1 \%)$ and did not increase treatment-related deaths (4.4\% vs. 5.6\%) (28). Interestingly, the control arm underperformed with a PFS of just 5.6 months. This may, at least in part, be explained by differences in the definition of PFS. Whereas 
prior trials have measured PFS from initiation of cCRT to disease progression (3), PFS in the PACIFIC trial was defined as the time from randomization, which occurred up to 42 days after completion of cCRT, to progression. Nevertheless, this does not entirely account for a 6 month difference in PFS from the RTOG-0617 trial.

Despite these robust responses, the importance of OS data from this trial cannot be understated, and it is unclear whether consolidative durvalumab prolongs time to relapse or truly increases rates of cure. Another element of uncertainty, albeit minor, is whether early (consolidative) or delayed (at the time of recurrence) durvalumab differentially impacts survival, as patients were not permitted to crossover from the observation to durvalumab arm. No trials have established a standard-of-care role for durvalumab in Stage IV NSCLC; however, pembrolizumab monotherapy would be standard of care for patients who progressed with observation after cCRT and whose tumors are strongly PD-L1-positive (13,29). The RTOG-3505 trial, which evaluates consolidative nivolumab against observation after cCRT and permits crossover from the observation arm, may definitively answer this question (Table 3) (30).

\section{Patient Selection and Biomarkers}

Beyond the need for accurate survival data, the ability to predict the need for and benefit of consolidative immunotherapy would be ideal, especially given the curability of cCRT alone and the cost of ICIs. To date, PD-L1 expression is the only biomarker that informs clinical use of ICIs (29). In the metastatic setting, first-line pembrolizumab yielded response rates of $44.8 \%$ in patients with PD-L1 expression $\geq 50 \%$ (13), yet, in the CheckMate-026 trial, first-line nivolumab was not superior to chemotherapy with only $26 \%$ of patients with PD-L1 expression $\geq 5 \%$ responding to nivolumab (Table 2) (14). Considerable discordance has been reported between 
each drug's accompanying PD-L1 assay, which may distort extrapolations from one trial to another (31). However, PD-L1 expression was also positively correlated with increased response rates, PFS, and OS of second-line atezolizumab, nivolumab, and pembrolizumab (9-12). Despite the limitations of PD-L1 assays, these studies collectively suggest PD-L1 expression influences the efficacy of PD-1/PD-L1 inhibitor monotherapy.

The PACIFIC trial did not select patients based on PD-L1 expression, and it reported that durvalumab reduced progression regardless of PD-L1 expression (28). It is possible that PD-L1 expression plays less of a role in combination therapy. In KEYNOTE-021 trial, for example, combination carboplatin, pemetrexed, and pembrolizumab yielded response rates of 57\% in patients with $<1 \%$ PD-L1 expression vs. 54\% in those with $\geq 1 \%$ PD-L1 expression (27). Nevertheless, the role of PD-L1 in patients with Stage III disease should not yet be discounted for several reasons. First, PD-L1 testing was not performed in over one-third of patients (28). Second, the trial analyzed PD-L1 as a binary variable, despite its continuous impact on outcomes (31). Notably, there was a trend toward decreasing risk of progression with durvalumab in patients with PD-L1 expression $\geq 25 \%$ (HR: 0.41 ; CI: 0.26-0.65) vs. <25\% (HR: 0.59; CI: $0.43-$ 0.82) (28). Whether the benefit of durvalumab dissipated with lower levels of PD-L1 expression is unclear, although the RTOG-3505 trial, which stratifies patients according to PD-L1 expression ( $<1 \%$ vs. $\geq 1 \%$ ), may clarify this (Table 3) (30). Another issue is the variability in PD-L1 assay itself. The companion antibody clone (SP142) used in the PD-L1 assays of the PACIFIC trial has considerable inter-observer variability and detects lower levels of PD-L1 compared to others (31), as it excludes immune cell PD-L1 expression (32). Finally, PD-L1 testing was performed on tissue obtained prior to therapy, which would not capture increases in 
PD-L1 expression after cCRT $(16,17,21,33)$. While post-cCRT PD-L1 expression would be more reliable, tissue re-biopsy may be unfeasible.

Other novel biomarkers have also been proposed. For example, the number of somatic tumor mutations positively correlates with neoantigen-specific $\mathrm{T}$ cell reactivity and pembrolizumab response (34). An exploratory analysis of the CheckMate-026 trial showed that tumor mutation burden is independent of and complimentary to PD-L1 expression as a biomarker of response (14). Patients with both high tumor mutation burden and $\geq 50 \%$ PD-L1 expression had a $75 \%$ response rate to nivolumab, while patients with $<50 \%$ PD-L1 expression and low tumor mutation burden had a response rate of just $16 \%$. Even so, tumor mutation burden, like PD-L1, could theoretically be affected by cCRT. Development of a serologic biomarker could circumvent the need for post-cCRT re-biopsy. One candidate is the protein BIM, the mediator of apoptosis following PD-1 activation (35). Plasma BIM levels were correlated with response to PD-1 inhibitors in one early study (36). Nevertheless, these emerging biomarkers will need to validated in patients receiving cCRT.

Another conundrum in patient selection, the efficacy of PD-1/PD-L1 ICIs in patients with targetable EGFR mutations and ALK translocations NSCLC, which are characterized by lower mutation burdens, is questionable (37). These patients were excluded from trials of first-line nivolumab and pembrolizumab in metastatic NSCLC $(13,14)$. None of the trials of second-line nivolumab, pembrolizumab, or atezolizumab reported benefit in patients with ALK-translocation (37), and one meta-analysis reported equivalency between these agents and docetaxel in the EGFR-mutant subgroup (38). Independent of immunotherapy, the optimal management of patients with EGFR-mutant or ALK-positive Stage III NSCLC is under active investigation with one trial of induction targeted therapy with erlotinib or crizotinib underway (39). In the PACIFIC 
trial, EGFR status was unknown in approximately one-fourth of patients (28). In the $6 \%$ of patients with known EGFR mutations, the benefit of durvalumab was unclear (HR: 0.76; CI 0.35-1.64). Patients with ALK translocations were not excluded from this study, but no data specific to their outcomes were reported. Further research into both targeted therapy and immunotherapy in these patients is needed to determine their optimal management.

\section{Future Directions: Toward the Optimal Regimen}

The PACIFIC trial raises questions regarding the timing between cCRT and immunotherapy. Consolidative durvalumab reduced progression regardless of when it was initiated (28). However, greater reductions were observed if durvalumab was initiated within $\leq 2$ weeks of radiation (HR: 0.39; CI: 0.26-0.58) rather than >2 weeks after radiation (HR: $0.63 \mathrm{CI}$ : 0.49-0.80), suggesting a critical window in which to initiate PD-L1 blockade. This corroborates retrospective studies which identified improved outcomes in patients treated with immunotherapy concurrently or in close proximity to radiation $(40,41)$. Ongoing trials of PD1/PD-L1 inhibitors, listed in Table 3, initiate immunotherapy at varying time points; their collective results may elucidate the ideal interval between cCRT and consolidative immunotherapy.

In terms of improving upon the results of the PACIFIC trial, perhaps the efficacy of immunotherapy after cCRT could be augmented with additional consolidative therapy. Given the potential for chemotherapy to synergize with PD-1/PD-L1 ICIs as demonstrated by the KEYNOTE-021 study, it is possible that adding platinum-doublet chemotherapy to consolidative immunotherapy could improve responses (27). Another prospect is dual immune checkpoint inhibition with a PD-1/PD-L1 ICI and the CTLA4 ICI ipilimumab, a regimen with high response 
rates in an early trial of patients with Stage IV NSCLC (42). One ongoing study, NCT03285321 (43), is currently studying this approach in patients with Stage III NSCLC using the combination of nivolumab and ipilimumab after cCRT (Table 3).

The impact of durvalumab on local disease control may also reveal a role for PD-1/PDL1 ICIs as induction or concurrent (during cCRT) therapy. Suboptimal locoregional control has remained a challenge after cCRT with 5-year in-radiation field recurrence rates of 25\%-29\% (1). Though radiation dose escalation may improve locoregional control (44), its toxicity to normal heart and lung tissue remains a limiting factor (3). Induction systemic therapy could theoretically improve both systemic and local control by treating systemic microscopic systemic disease early and reducing tumor volumes to allow for radiation fields more amenable to dose escalation. However, such an approach has historically been limited by poor responses to chemotherapy (44). Data from the PACIFIC trial suggest that PD-1/PD-L1 ICIs could fill this role, as consolidative durvalumab significantly increased intra-thoracic responses $(28.4 \%$ vs. $16 \%$; $\mathrm{p}<0.001$ ) (28). One Phase II trial (NCT03102242) testing a regimen of cCRT preceded and followed by induction and adjuvant atezolizumab will help to characterize responses to induction immunotherapy in patients with Stage III NSCLC (Table 3) (45).

Another investigational strategy to safely increase radiation doses is dose adaptation during cCRT. In the RTOG-1106 trial, for example, patients are re-simulated with PET-CT after the first 21 fractions of cCRT (46). Should interval reductions in tumor volumes allow for dose escalation, primary tumors are then treated to 80.4 Gy. Given the impact of durvalumab on intrathoracic disease, perhaps concurrent tri-modality therapy (PD-1/PD-L1 ICIs and chemoradiation) could better facilitate dose adaptation and escalation. Two early trials, NCT02434081 and NCT02621398, are testing nivolumab (47) or pembrolizumab (48), 
respectively, given concurrently and adjuvantly with respect to cCRT (Table 3). These trials may determine not just whether concurrent tri-modality therapy is tolerable enough to justify dose adaptation, but also whether anti-tumor activity is potentiated with this approach.

In conclusion, preliminary data support the potential of ICIs after cCRT to improve both local and systemic disease control of unresectable Stage III NSCLC, although we cautiously await reports of OS from the PACIFIC trial and others. Future research into the development of accurate biomarkers, such as PD-L1 expression and tumor mutation burden, and into the optimal timing between chemoradiation and immunotherapy will be critical. The PACIFIC trial raises even more therapeutic possibilities, including induction immunotherapy, radiation dose adaptation, and combination consolidative therapy. Regardless, it represents a step toward finally improving the dismal prognosis of locally advanced NSCLC after nearly two decades of efforts. 
Table 1. Multi-institutional Phase III Trials of Consolidative or Induction Systemic Therapy after concurrent chemoradiation for unresectable Stage III NSCLC.

\begin{tabular}{|c|c|c|c|}
\hline Trial & $\begin{array}{l}\text { Induction or Consolidative } \\
\text { Therapy with cCRT }\end{array}$ & $\begin{array}{c}\text { PFS } \\
\text { (months) } \\
\text { (P-value) }\end{array}$ & $\begin{array}{c}\text { OS } \\
\text { (months) } \\
\text { (P-value) }\end{array}$ \\
\hline $\begin{array}{l}\text { CALGB-39801 } \\
\text { (5) }\end{array}$ & $\begin{array}{c}\text { Carboplatin + Paclitaxel } \\
\text { (induction) }\end{array}$ & 7 vs. 8 (NS) & 12 vs. $14(\mathrm{NS})$ \\
\hline $\begin{array}{c}\text { HOG LU-0124 } \\
\text { (6) }\end{array}$ & $\begin{array}{c}\text { Docetaxel } \\
\text { (consolidation) }\end{array}$ & 10.8 vs. 10.3 (NS) & 24.2 vs. 26.1 (NS) \\
\hline $\begin{array}{l}\text { Korean Cancer } \\
\text { Study Group - } \\
\text { LU05-04 (2) }\end{array}$ & $\begin{array}{c}\text { Cisplatin } \\
+ \\
\text { Docetaxel } \\
\text { (consolidation) }\end{array}$ & 9.1 vs. $8.1(\mathrm{NS})$ & 21.8 vs. $21.6(\mathrm{NS})$ \\
\hline $\begin{array}{l}\text { RTOG-0617 } \\
(3)^{*}\end{array}$ & $\begin{array}{c}\text { Cetuximab } \\
\text { (consolidation) }\end{array}$ & 10.8 vs. 10.7 (NS) & 25 vs. 24 (NS) \\
\hline $\begin{array}{l}\text { SWOG-S0023 } \\
\text { (7) }\end{array}$ & $\begin{array}{c}\text { Docetaxel followed by } \\
\text { Gefitinib } \\
\text { (consolidation) }\end{array}$ & 8.3 vs. 11.7 (NS) & 23 vs. $35(p=0.013)$ \\
\hline START $(8)^{* *}$ & $\begin{array}{c}\text { Tecemotide } \\
\text { (consolidation) }\end{array}$ & $\begin{array}{l}14.2 \text { vs. } 11.4 \\
(p=0.02)\end{array}$ & 30.8 vs. 20.6 ( $\mathrm{p}=0.016)$ \\
\hline PACIFIC (28) & $\begin{array}{c}\text { Durvalumab } \\
\text { (consolidation) }\end{array}$ & $\begin{array}{l}16.8 \text { vs. } 5.6 \\
(p<0.0001)\end{array}$ & Ongoing \\
\hline
\end{tabular}


Table 2. Phase III Trials of PD-1/PD-L1 Inhibitors in Patients with Metastatic or Recurrent NSCLC

\begin{tabular}{|c|c|c|c|c|c|c|}
\hline Trial & Hist. & $\begin{array}{l}\text { PD-L1 } \\
\text { Exp. }\end{array}$ & $\begin{array}{c}\text { Experimental } \\
\text { vs. Control } \\
\text { Arms }\end{array}$ & $\begin{array}{c}1^{\text {st }} \\
\text { or } 2^{\text {nd }} \\
\text { Line } \\
\text { Therapy }\end{array}$ & $\begin{array}{c}\text { PFS } \\
\text { (months) } \\
\text { (P-value) }\end{array}$ & $\begin{array}{c}\text { OS } \\
\text { (months) } \\
\text { (P-value) }\end{array}$ \\
\hline $\begin{array}{l}\text { KEYNOTE-010 } \\
(10)^{*}\end{array}$ & Any & $\geq 1 \%$ & $\begin{array}{c}\text { Pembrolizumab } \\
(2 \mathrm{mg} / \mathrm{kg} \text { or } \\
10 \mathrm{mg} / \mathrm{kg}, \\
\text { respectively }) \\
\text { vs. Docetaxel }\end{array}$ & $\begin{array}{l}\text { Second } \\
\text { Line }\end{array}$ & $\begin{array}{c}3.9 \text { and } 4.0 \\
\text { vs. } 4.0 \\
\text { (NS, NS) }\end{array}$ & $\begin{array}{c}10.4 \text { and } \\
12.7 \text { vs. } 8.5 \\
(\mathrm{p}=0.008, \\
\mathrm{p}<0.001)\end{array}$ \\
\hline $\begin{array}{c}\text { CheckMate-017 } \\
\text { (12) }\end{array}$ & Squamous & Any & $\begin{array}{l}\text { Nivolumab vs. } \\
\text { Docetaxel }\end{array}$ & $\begin{array}{l}\text { Second } \\
\text { Line }\end{array}$ & $\begin{array}{l}3.5 \text { vs. } 2.8 \\
(p<0.001)\end{array}$ & $\begin{array}{l}9.2 \text { vs. } 6.0 \\
(p<0.001)\end{array}$ \\
\hline $\begin{array}{c}\text { CheckMate- } 057 \\
\text { (11) }\end{array}$ & $\begin{array}{c}\text { Non- } \\
\text { squamous }\end{array}$ & Any & $\begin{array}{l}\text { Nivolumab vs. } \\
\text { Docetaxel }\end{array}$ & $\begin{array}{l}\text { Second } \\
\text { Line }\end{array}$ & $\begin{array}{l}2.3 \text { vs. } 4.2 \\
\quad(\mathrm{NS})\end{array}$ & $\begin{array}{c}12.2 \text { vs. } 9.5 \\
(\mathrm{p}=0.002)\end{array}$ \\
\hline $\begin{array}{l}\text { OAK } \\
(9)\end{array}$ & Any & Any & $\begin{array}{l}\text { Atezolizumab } \\
\text { vs. Docetaxel }\end{array}$ & $\begin{array}{l}\text { Second } \\
\text { Line }\end{array}$ & $\begin{array}{l}2.8 \text { vs. } 4.0 \\
\quad(\mathrm{NS})\end{array}$ & $\begin{array}{c}13.8 \text { vs. } 9.6 \\
(p=0.003)\end{array}$ \\
\hline $\begin{array}{c}\text { KEYNOTE-024 } \\
\text { (13) }\end{array}$ & Any & $\geq 50 \%$ & $\begin{array}{c}\text { Pembrolizumab } \\
\text { vs. } \\
\text { Investigators' } \\
\text { Choice } \\
\text { Chemotherapy }\end{array}$ & $\begin{array}{l}\text { First } \\
\text { Line }\end{array}$ & $\begin{array}{c}10.3 \text { vs. } 6.0 \\
(p<0.001)\end{array}$ & $\begin{array}{c}30.0 \text { vs. } \\
14.2 \\
(\mathrm{p}=0.002)\end{array}$ \\
\hline $\begin{array}{c}\text { CheckMate-026 } \\
\text { (14) }\end{array}$ & Any & $\geq 5 \%$ & $\begin{array}{l}\text { Nivolumab vs. } \\
\text { Investigators' } \\
\text { Choice } \\
\text { Chemotherapy }\end{array}$ & $\begin{array}{l}\text { First } \\
\text { Line }\end{array}$ & $\begin{array}{l}4.2 \text { vs. } 5.9 \\
\text { (NS) }\end{array}$ & $\begin{array}{c}14.2 \text { vs. } \\
13.2(\mathrm{NS})\end{array}$ \\
\hline \multicolumn{7}{|c|}{$\begin{array}{l}\text { Hist: Histology; Exp: Expression PFS: Progression-free survival OS: Overall Survival NS: } \\
\text { Not statistically significant. } \\
\text { All values from clinical trials are presented as experimental arm value vs. control arm value. } \\
\text { *Survival data are reported as follows: pembrolizumab }(2 \mathrm{mg} / \mathrm{kg}) \text { and pembrolizumab } \\
(10 \mathrm{mg} / \mathrm{kg}) \text { vs. docetaxel. P-values are reported as: (pembrolizumab }(2 \mathrm{mg} / \mathrm{kg}) \text { vs docetaxel; } \\
\text { pembrolizumab }(10 \mathrm{mg} / \mathrm{kg} \text { ) vs docetaxel) }\end{array}$} \\
\hline
\end{tabular}


Table 3. Ongoing Studies Incorporating PD-1/PD-L1 ICIs into cCRT regimens in the Treatment of Stage III NSCLC

\begin{tabular}{|c|c|c|c|}
\hline $\begin{array}{c}\text { Study } \\
\text { RTOG-3505 } \\
(30)\end{array}$ & III & Nivolumab vs. Observation & $\begin{array}{c}\text { Timing of Immunotherapy } \\
\text { Initiation }\end{array}$ \\
\hline $\begin{array}{c}\text { NCT03285321 } \\
(43)\end{array}$ & II & $\begin{array}{c}\text { Nivolumab + Ipilimumab vs. } \\
\text { Nivolumab alone } \\
\text { completion }\end{array}$ & $\begin{array}{c}\text { 28-56 days after cCRT } \\
\text { completion }\end{array}$ \\
\hline $\begin{array}{c}\text { NCT03102242 } \\
(45)\end{array}$ & II & $\begin{array}{c}\text { Atezolizumab (induction and } \\
\text { adjuvant) }\end{array}$ & $\begin{array}{c}\text { Induction: 2 or 4 3-week cycles } \\
\text { Adjuvant: 3-5 weeks after cCRT } \\
\text { completion }\end{array}$ \\
\hline $\begin{array}{c}\text { NCT02434081 } \\
(47)\end{array}$ & II & $\begin{array}{c}\text { Nivolumab (concurrent and } \\
\text { adjuvant) }\end{array}$ & $\begin{array}{c}\text { Within 30 days of first cycle of } \\
\text { chemotherapy }\end{array}$ \\
\hline $\begin{array}{c}\text { NCT02621398 } \\
(48)\end{array}$ & I & $\begin{array}{c}\text { Pembrolizumab (concurrent } \\
\text { and adjuvant) }\end{array}$ & $\begin{array}{c}\text { Same day as cCRT initiated } \\
\text { cCRT: Concurrent chemoradiation therapy }\end{array}$ \\
\hline
\end{tabular}




\section{Figure Legend}

Figure 1. Immunogenic Synergy between Chemoradiation and PD-L1 Inhibitors.

Chemoradiation increases tumor antigen release, and induces DNA-breaks, which increase ATP, HMGB1, interferons (INF), and translation of calreticulin (CRT). Collectively, this activates APCs, which migrate to the lymph nodes and prime CD8+ T cells with tumor antigen. The addition of PD-1/PD-L1 blockade inhibits T cell exhaustion, facilitating anti-tumor immunity.

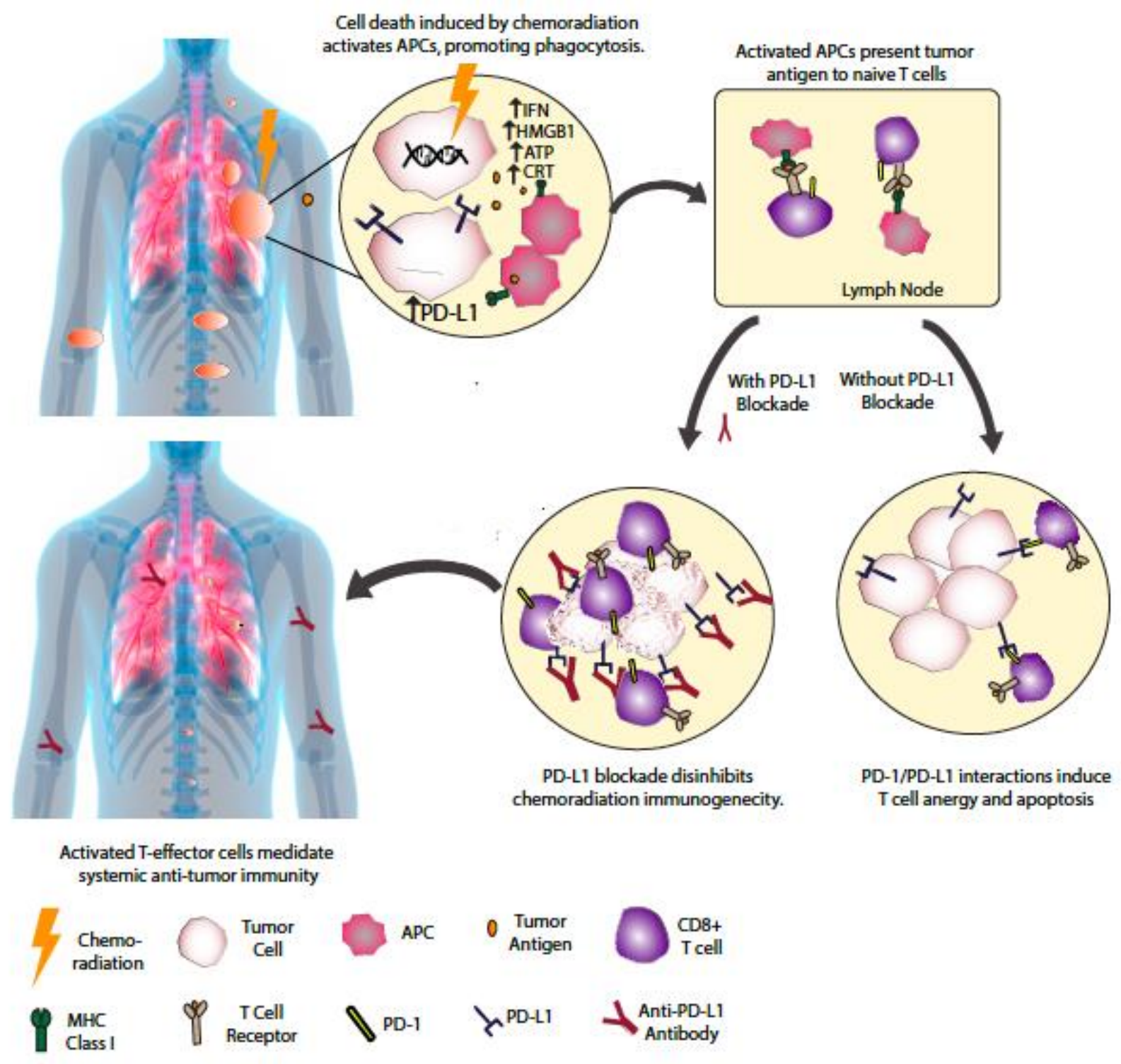




\section{Bibliography}

1. Curran WJ, Paulus R, Langer CJ, Komaki R, Lee JS, Hauser S, et al. Sequential vs. concurrent chemoradiation for stage III non-small cell lung cancer: randomized phase III trial RTOG 9410. J Natl Cancer Inst. 2011;103:1452-60.

2. Ahn JS, Ahn YC, Kim J-H, Lee CG, Cho EK, Lee KC, et al. Multinational Randomized Phase III Trial With or Without Consolidation Chemotherapy Using Docetaxel and Cisplatin After Concurrent Chemoradiation in Inoperable Stage III Non-Small-Cell Lung Cancer: KCSG-LU05-04. J Clin Oncol. 2015;33:2660-6.

3. Bradley JD, Paulus R, Komaki R, Masters G, Blumenschein G, Schild S, et al. Standarddose versus high-dose conformal radiotherapy with concurrent and consolidation carboplatin plus paclitaxel with or without cetuximab for patients with stage IIIA or IIIB non-small-cell lung cancer (RTOG 0617): a randomised, two-by-two factorial phase 3 
study. Lancet Oncol. 2015;16:187-99.

4. Gore EM, Bae K, Wong SJ, Sun A, Bonner JA, Schild SE, et al. Phase III comparison of prophylactic cranial irradiation versus observation in patients with locally advanced nonsmall-cell lung cancer: primary analysis of radiation therapy oncology group study RTOG 0214. J Clin Oncol. 2011;29:272-8.

5. Vokes EE, Herndon JE, Kelley MJ, Cicchetti MG, Ramnath N, Neill H, et al. Induction chemotherapy followed by chemoradiotherapy compared with chemoradiotherapy alone for regionally advanced unresectable stage III Non-small-cell lung cancer: Cancer and Leukemia Group B. J Clin Oncol. 2007;25:1698-704.

6. Hanna N, Neubauer M, Yiannoutsos C, McGarry R, Arseneau J, Ansari R, et al. Phase III study of cisplatin, etoposide, and concurrent chest radiation with or without consolidation docetaxel in patients with inoperable stage III non-small-cell lung cancer: the Hoosier Oncology Group and U.S. Oncology. J Clin Oncol. 2008;26:5755-60.

7. Kelly K, Chansky K, Gaspar LE, Albain KS, Jett J, Ung YC, et al. Phase III trial of maintenance gefitinib or placebo after concurrent chemoradiotherapy and docetaxel consolidation in inoperable stage III non-small-cell lung cancer: SWOG S0023. J Clin Oncol. 2008;26:2450-6.

8. Butts C, Socinski MA, Mitchell PL, Thatcher N, Havel L, Krzakowski M, et al. Tecemotide (L-BLP25) versus placebo after chemoradiotherapy for stage III non-small-cell lung cancer (START): a randomised, double-blind, phase 3 trial. Lancet Oncol. 2014;15:59-68.

9. Rittmeyer A, Barlesi F, Waterkamp D, Park K, Ciardiello F, Pawel J von, et al. Atezolizumab versus docetaxel in patients with previously treated non-small-cell lung cancer (OAK): a phase 3, open-label, multicentre randomised controlled trial. The Lancet. 2017;389:255-65.

10. Herbst RS, Baas P, Kim D-W, Felip E, Pérez-Gracia JL, Han J-Y, et al. Pembrolizumab versus docetaxel for previously treated, PD-L1-positive, advanced non-small-cell lung cancer (KEYNOTE-010): a randomised controlled trial. The Lancet. 2016;387:1540-50.

11. Borghaei H, Paz-Ares L, Horn L, Spigel DR, Steins M, Ready NE, et al. Nivolumab versus Docetaxel in Advanced Nonsquamous Non-Small-Cell Lung Cancer. N Engl J Med. 2015;373:1627-39.

12. Brahmer J, Reckamp KL, Baas P, Crinò L, Eberhardt WEE, Poddubskaya E, et al. Nivolumab versus Docetaxel in Advanced Squamous-Cell Non-Small-Cell Lung Cancer. N Engl J Med. 2015;373:123-35.

13. Reck M, Rodríguez-Abreu D, Robinson AG, Hui R, Csőszi T, Fülöp A, et al. Pembrolizumab versus Chemotherapy for PD-L1-Positive Non-Small-Cell Lung Cancer. N 
Engl J Med. 2016;375:1823-33.

14. Carbone DP, Reck M, Paz-Ares L, Creelan B, Horn L, Steins M, et al. First-Line Nivolumab in Stage IV or Recurrent Non-Small-Cell Lung Cancer. N Engl J Med. 2017;376:2415-26.

15. Brahmer J, Rodriguez-Abreu D, Robinson A, Hui R, Csoszi T, Fulop A, et al. OA 17.06 Updated Analysis of Keynote-024: Pembrolizumab vs Platinum-based Chemotherapy for Advanced NSCLC with PD-L1 TPS >50\%. OA 17 Immunotherapy II.

16. Takamori S, Toyokawa G, Takada K, Shoji F, Okamoto T, Maehara Y. Combination Therapy of Radiotherapy and Anti-PD-1/PD-L1 Treatment in Non-Small-cell Lung Cancer: A Mini-review. Clin Lung Cancer. 2017;

17. Funaki S, Shintani Y, Kawamura T, Kanzaki R, Minami M, Okumura M. Chemotherapy enhances programmed cell death 1/ligand 1 expression via TGF- $\beta$ induced epithelial mesenchymal transition in non-small cell lung cancer. Oncol Rep. 2017;38:2277-84.

18. Dovedi SJ, Adlard AL, Lipowska-Bhalla G, McKenna C, Jones S, Cheadle EJ, et al. Acquired resistance to fractionated radiotherapy can be overcome by concurrent PD-L1 blockade. Cancer Res. 2014;74:5458-68.

19. Formenti SC. Optimizing dose per fraction: A new chapter in the story of the abscopal effect? International Journal of Radiation Oncology*Biology*Physics. 2017;99:677-9.

20. Golden EB, Frances D, Pellicciotta I, Demaria S, Helen Barcellos-Hoff M, Formenti SC. Radiation fosters dose-dependent and chemotherapy-induced immunogenic cell death. Oncoimmunology. 2014;3:e28518.

21. Wu C-T, Chen W-C, Chang Y-H, Lin W-Y, Chen M-F. The role of PD-L1 in the radiation response and clinical outcome for bladder cancer. Sci Rep. 2016;6:19740.

22. Dovedi SJ, Cheadle EJ, Popple AL, Poon E, Morrow M, Stewart R, et al. Fractionated Radiation Therapy Stimulates Antitumor Immunity Mediated by Both Resident and Infiltrating Polyclonal T-cell Populations when Combined with PD-1 Blockade. Clin Cancer Res. 2017;23:5514-26.

23. Peng J, Hamanishi J, Matsumura N, Abiko K, Murat K, Baba T, et al. Chemotherapy Induces Programmed Cell Death-Ligand 1 Overexpression via the Nuclear Factor- $\mathrm{\kappa B}$ to Foster an Immunosuppressive Tumor Microenvironment in Ovarian Cancer. Cancer Res. 2015;75:5034-45.

24. Tumeh PC, Harview CL, Yearley JH, Shintaku IP, Taylor EJM, Robert L, et al. PD-1 blockade induces responses by inhibiting adaptive immune resistance. Nature. 2014;515:568-71. 
25. Gibbons RM, Liu X, Pulko V, Harrington SM, Krco CJ, Kwon ED, et al. B7-H1 limits the entry of effector CD8(+) T cells to the memory pool by upregulating Bim.

Oncoimmunology. 2012;1:1061-73.

26. Shaverdian N, Lisberg AE, Bornazyan K, Veruttipong D, Goldman JW, Formenti SC, et al. Previous radiotherapy and the clinical activity and toxicity of pembrolizumab in the treatment of non-small-cell lung cancer: a secondary analysis of the KEYNOTE-001 phase 1 trial. Lancet Oncol. 2017;18:895-903.

27. Langer CJ, Gadgeel SM, Borghaei H, Papadimitrakopoulou VA, Patnaik A, Powell SF, et al. Carboplatin and pemetrexed with or without pembrolizumab for advanced, nonsquamous non-small-cell lung cancer: a randomised, phase 2 cohort of the open-label KEYNOTE-021 study. Lancet Oncol. 2016;17:1497-508.

28. Antonia SJ, Villegas A, Daniel D, Vicente D, Murakami S, Hui R, et al. Durvalumab after Chemoradiotherapy in Stage III Non-Small-Cell Lung Cancer. N Engl J Med. 2017;

29. Hanna N, Johnson D, Temin S, Baker S, Brahmer J, Ellis PM, et al. Systemic Therapy for Stage IV Non-Small-Cell Lung Cancer: American Society of Clinical Oncology Clinical Practice Guideline Update. J Clin Oncol. 2017;JCO2017746065.

30. Randomized phase III trial of concurrent chemoradiation followed by nivolumab or placebo for locally advanced non-small cell lung cancer (NSCLC) (RTOG 3505).: Journal of Clinical Oncology: Vol 35, No 15_suppl. J Clin Oncol [Internet]. Available from: http://ascopubs.org/doi/abs/10.1200/JCO.2017.35.15_suppl.TPS8579

31. Büttner R, Gosney JR, Skov BG, Adam J, Motoi N, Bloom KJ, et al. Programmed DeathLigand 1 Immunohistochemistry Testing: A Review of Analytical Assays and Clinical Implementation in Non-Small-Cell Lung Cancer. J Clin Oncol. 2017; JCO2017747642.

32. Kerr KM, Nicolson MC. Non-Small Cell Lung Cancer, PD-L1, and the Pathologist. Arch Pathol Lab Med. 2016;140:249-54.

33. Black M, Barsoum IB, Truesdell P, Cotechini T, Macdonald-Goodfellow SK, Petroff M, et al. Activation of the PD-1/PD-L1 immune checkpoint confers tumor cell chemoresistance associated with increased metastasis. Oncotarget. 2016;7:10557-67.

34. Rizvi NA, Hellmann MD, Snyder A, Kvistborg P, Makarov V, Havel JJ, et al. Cancer immunology. Mutational landscape determines sensitivity to PD-1 blockade in non-small cell lung cancer. Science. 2015;348:124-8.

35. Dronca RS, Liu X, Harrington SM, Chen L, Cao S, Kottschade LA, et al. T cell Bim levels reflect responses to anti-PD-1 cancer therapy. JCI Insight [Internet]. 2016; Available from: https://insight.jci.org/articles/view/86014

36. Bim and soluble PD-L1 (sPD-L1) as predictive biomarkers of response to anti-PD-1 
therapy in patients with melanoma and lung carcinoma.: Journal of Clinical Oncology: Vol 35, No 15_suppl. J Clin Oncol [Internet]. Available from:

http://ascopubs.org/doi/abs/10.1200/JCO.2017.35.15_suppl.11534

37. Bylicki O, Paleiron N, Margery J, Guisier F, Vergnenegre A, Robinet G, et al. Targeting the PD-1/PD-L1 Immune Checkpoint in EGFR-Mutated or ALK-Translocated Non-SmallCell Lung Cancer. Target Oncol. 2017;

38. Lee CK, Man J, Lord S, Links M, Gebski V, Mok T, et al. Checkpoint Inhibitors in Metastatic EGFR-Mutated Non-Small Cell Lung Cancer-A Meta-Analysis. J Thorac Oncol. 2017;12:403-7.

39. Erlotinib Hydrochloride or Crizotinib and Chemoradiation Therapy in Treating Patients With Stage III Non-small Cell Lung Cancer - Full Text View - ClinicalTrials.gov [Internet]. [cited 2017 Nov 6]. Available from: https://clinicaltrials.gov/ct2/show/NCT01822496

40. Srivastava A, Huang J. The Impact of the Timing of PD-1 Inhibition on Disease Control for Brain Metastases Treated with Stereotactic Radiosurgery. International Journal of Radiation Oncology*Biology*Physics. 2017;99:E111.

41. Samstein R, Rimner A, Barker CA, Yamada Y. Combined Immune Checkpoint Blockade and Radiation Therapy: Timing and Dose Fractionation Associated with Greatest Survival Duration Among Over 750 Treated Patients. International Journal of Radiation Oncology*Biology*Physics. 2017;99:S129-30.

42. Hellmann MD, Rizvi NA, Goldman JW, Gettinger SN, Borghaei H, Brahmer JR, et al. Nivolumab plus ipilimumab as first-line treatment for advanced non-small-cell lung cancer (CheckMate 012): results of an open-label, phase 1, multicohort study. Lancet Oncol. 2017;18:31-41.

43. Unresectable Stage IIIA/IIIB Non-small Cell Lung Cancer (NSCLC) - Full Text View ClinicalTrials.gov [Internet]. [cited 2017 Oct 18]. Available from: https://clinicaltrials.gov/ct2/show/NCT03285321?term=nivolumab\&recrs=ab\&cond=Non+ Small+Cell+Lung+Cancer+Stage+IIIB \&draw $=1 \&$ rank $=12$

44. Terakedis B, Sause W. Radiation Dose Escalation in Stage III Non-Small-Cell Lung Cancer. Front Oncol. 2011;1:47.

45. Phase II Trial of Induction Immunotherapy With Atezolizumab for Patients With Unresectable Stage IIIA and IIIB NSCLC Eligible for Chemoradiotherapy With Curative Intent. [Internet]. ClinicalTrials.gov. [cited 2017 Nov 1]. Available from: https://clinicaltrials.gov/ct2/show/NCT03102242

46. Study of Positron Emission Tomography and Computed Tomography in Guiding Radiation Therapy in Patients With Stage III Non-small Cell Lung Cancer - Full Text View - 
ClinicalTrials.gov [Internet]. [cited 2017 Nov 6]. Available from:

https://clinicaltrials.gov/ct2/show/NCT01507428

47. NIvolumab COmbination With Standard First-line Chemotherapy and Radiotherapy in Locally Advanced Stage IIIA/B Non-Small Cell Lung Carcinoma (NICOLAS) [Internet]. Clinicaltrials.gov. [cited 2017 Oct 19]. Available from:

https://clinicaltrials.gov/ct2/show/NCT02434081

48. Pembrolizumab, Paclitaxel, Carboplatin, and Radiation Therapy in Treating Patients With Stage II-IIIB Non-Small Cell Lung Cancer - Full Text View - ClinicalTrials.gov [Internet]. [cited 2017 Oct 20]. Available from: https://clinicaltrials.gov/ct2/show/NCT02621398 